\title{
Flooding protection management for risk prevention in arid catchments
}

\begin{abstract}
The integration of hydrological parameters was used for the water balance in arid catchments to assess the storm runoff frequency distributions. A Digital Elevation Model (DEM) for the Marar catchment in the Jordan Rift Valley was used for the rainfall and evaporation simulations. Runoff peak discharge was estimated using the curve number method and unit hydrographs from Ramallah Meteorological Station. The runoff storm average is 2.35 million cubic meters per year in a ten year cycle (2004/2014) representing of $9.8 \%(183 \mathrm{~mm})$ of precipitation per year. Derivations of unit hydrographs for 10 to 25 years reveals for peak discharge between 22.8-29.4 and $35.3-45.5 \mathrm{~m} / \mathrm{s}$ respectively. The annual recharge was calculated for to be between $113.3-83 \mathrm{~mm} /$ year using different methodologies. The appropriate method for solving flood control and avoiding flood catastrophe is in constructing small scale retention dams and the availability of stored runoff water will be used for agricultural or touristic use.
\end{abstract}

Keywords: marar catchmen, floods, risk management, West bank
Volume I Issue 4 - 2017

\author{
Marwan Ghanem,' Abdelrahman Tamimi, ${ }^{2}$ \\ Zakaria Al Haj $\mathrm{Ali}^{3}$ \\ 'Birzeit University, West Bank \\ ${ }^{2}$ Palestinian Hydrology Group, West Bank \\ ${ }^{3}$ Ministry of Water and Irrigation, West Bank
}

Correspondence: Marwan Ghanem, Birzeit University, West Bank, Email mghanem@birzeit.edu

Received: September 09, 2017 | Published: November 09, 2017

\section{Introduction}

Marar catchment is located in an arid to semi-arid region where the conservation of water resources is not significant. The increase in demand for water in Marar catchment should lead to the implementation of high intensive water management measures to achieve efficient utilization of the limited available water supplies. Marar catchment's steep slopes and geology make it among the most likely in the West Bank to experience floods. Floods flow with high speeds and in large quantities without human benefit is one of the major concerns to be taken into consideration. Studying the hydrological, hydrogeological, geomorphological, and water balance of the catchment will help in choosing the appropriate method for solving the flood problems in the area. The area of the study lies in the eastern part of the West Bank and located within structural and hydrological boundaries. The main recharge sub-basin for this system is the Jerusalem-Ramallah Mountains in which runoff water drains through wadi's flow from the west to the Jordan Rift Valley in the east.

\section{Geography of the study area}

Marar catchment is part of the eastern basin and has an area of $98.3 \mathrm{~km}^{2}$. It starts from the western central mountains, located between Ramallah and Jerusalem in the western part of the West Bank and slopes steeply toward the Jordan valley in the eastern part of the West Bank forming the sub-basin of the Jordan River-Dead Sea basin. The length of Wadi' Marar with its tributaries ranges between $25-20 \mathrm{~km}$. It is characterized by a steep relief and varies in elevation from 500 meters above sea level (m.a.s.l) in the west to -300 meters below sea level (m.b.s.l) in the east, which reflects relatively steep sloping. ${ }^{1}$ The total Palestinian population in the Marar catchment is 35,935 inhabits ${ }^{2}$ from the cities, communities and refugees camps and three Israeli colonies with settlers estimated to be 15,000 inhabitants living in the area. ${ }^{2}$ The area is affected by two wind directions throughout the day. ${ }^{3}$ The temperature increases from north to south and from west to east, contrary to the altitude. January is the coldest month and August is the warmest. Moist air masses from the Mediterranean bring most of the rain that falls on the western part of Marar catchment. RamallahJerusalem upper mountains have an annual rainfall ranging between 500 to $700 \mathrm{~mm} /$ year. $^{4}$ The rainfall values decrease down east ranging between 150-200 mm/year. ${ }^{5}$ The catchment has high floods as a result of its steep slopes. ${ }^{5}$ Marar catchment consists of Quaternary and Upper Cretaceous Formations. ${ }^{6}$ The depth to the ground water in the Upper Cretaceous formations ranges from $190 \mathrm{~m}$ to $490 \mathrm{~m}$. It is divided mainly into three Groups: Cenomanian, Turonian and Quaternary Rock formations. Cenomanian group rocks are composed of brittle karstified, gray dolomite, dolomitic limestone and gray limestone. Its base is formed of hard dolomite and dolomitic limestone with some silicification. Turonian Group formation covers the western and north western of the study area, its lithology is characterized by karstified limestone and dolomite with marl and clay mainly near the bottom. The occurrence of chalk is evident on the top of this formation. In the Quaternary formation, Pleistocene to Eocene age rocks composed mainly of limestone, chalks, marls, and siltstone. The Neogene and Quaternary successions are built mainly of marine and continental clastic formations, marine and limnic chalk, evaporates and magmatic rocks. ${ }^{4}$ These deposits are inter-fingering with the lacustrine sediments of the lisan formation. ${ }^{78}$ The geological map of Marar Catchment is illustrated in Figure 1. The water level along Ramallah anticlinal axes is about $+450 \mathrm{~m}$ and declines eastward in the direction of the Jericho area to level about -300 and -350 in the lower and upper sub-aquifers. Water levels show general decreases towards east. The changes in aquifer hydraulic properties from west to east, as well as the high abstraction rate are the main causes of the decline in groundwater level. ${ }^{9}$ A large number of active boreholes have been drilled mostly at two locations. The first is located along the foothills and exploits water from the upper cretaceous aquifer; while the second location is located in the Jordan Valley and abstracts water from the Jordan Valley deposits aquifer. 


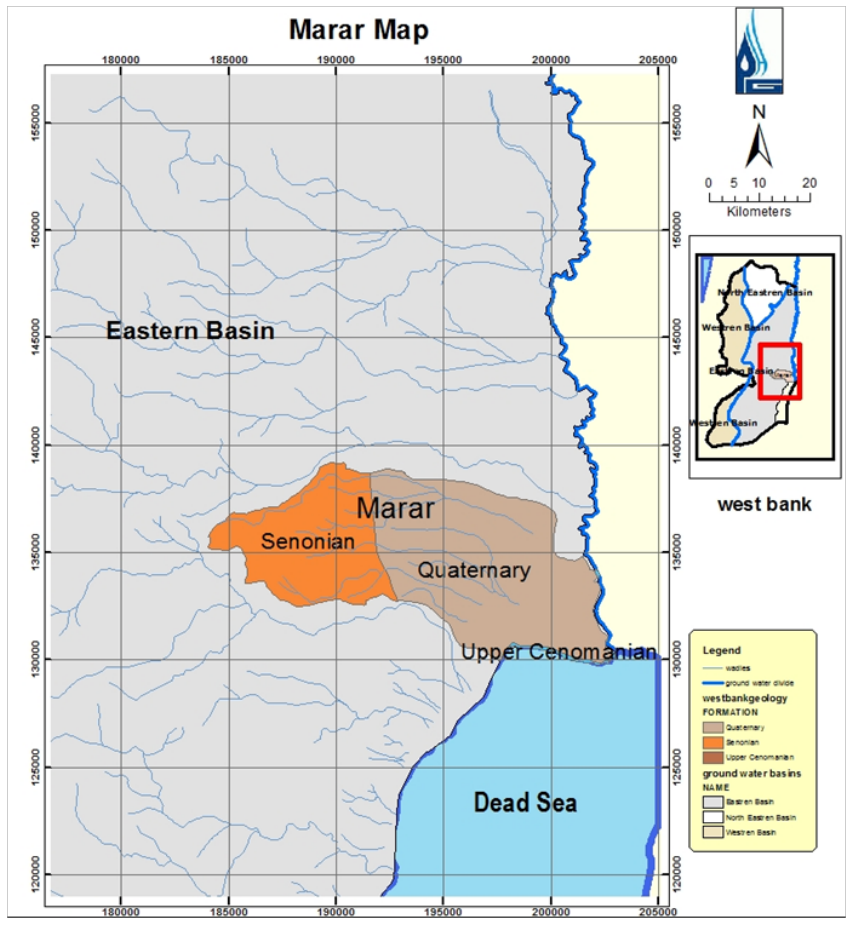

Figure I Geological map of marar catchment.

\section{Literature review}

Storm water drainage is as important in arid and semiarid regions as in humid regions because not only is it a drainage problem, but additionally, it is a water resources management and planning issue. In the West Bank, storm water drainage has not been given enough care and no intensive studies have been done. The runoff to rainfall ratio in the West Bank proved to be considerably variable with no clear relation controlling the process. ${ }^{10}$ The geological, geomorphological and hydrological features along the course of the Wadi Gaza (Palestine) confirm the existence of Pleistocene loess Sediments along the Wadi. ${ }^{11}$ Wadi Gaza is characterized by meandering features along its course. Storm water drains the hills and mountains of Hebron and the northern Negev desert, accumulates in the Beer-Sheva area, crosses the Gaza Strip and discharges into the Mediterranean Sea. In winter the Wadi Gaza brings about 20 million cubic meter of rainwater into the area. The risk of flood in the West Bank-Palestine studied by Abu Safat ${ }^{12}$ tackles floods in the West-Bank in two cases of Marj Sanour and Wadi Al Zumar as events accompanied with negative economic, logistic and urban impacts, in addition to the temporary disturbance of daily life in the areas where a flood takes place. Analysis of flash flood regimes in the North-Western and South-Eastern Mediterranean regions was studied by Tarolli et al. ${ }^{13}$ The characteristics of flash flood regimes in two Mediterranean areas: the North-Western Mediterranean region is analyzed, which includes Catalonia, France and Northern Italy, and the South-Eastern Mediterranean region. Results show that the envelope curve for the South-Eastern region exhibits a more pronounced decreasing with catchment size with respect to the curve of the North-Western region. The differences between the two relationships reflect changes in the effects of storm coverage and hydrological characteristics between the two regions. Flash food risk estimation of Wadi Yutum (southern Jordan) watershed using GIS based morphometric analysis and a remote sensing technique was carried out. ${ }^{14}$ The results achieved based on the two methods enabled identification of sub-basins with a high potential of flash flooding, and served to reveal the common sub-basins falling under each category of flooding risk. Flash floods and hydro-geomorphic response acts as risk management integrations. Different methodologies were used in order to prevent flooding risks. ${ }^{15}$ Risk assessment due to potential flash floods hazards in Wadi Mousa was studied by Alhasanat ${ }^{16}$ to determine the magnitude of flows for flash flood hazards and construct floodplain zone maps for the selected flood return periods of 25, 50, 75 and 100 years. Wadi Mousa is considered an ephemeral wadi with intermittent flash flood of flows that can exceed the $298 \mathrm{~m}^{3} / \mathrm{s}$ threshold. Its floods, however, do not flow every year. Recurring flood events reveal that flood risk management is a continuous task. Hence, risk drivers, such as climate change, land-use changes, economic developments, or demographic change and the resultant risks must be investigated at regular intervals, and risk reduction strategies and processes must be reassessed as well as adapted and implemented in a dialogue with all stakeholders. ${ }^{17}$

\section{Methodology}

Field visits were carried out in order to study the physio-geographic characteristics of the catchment. GIS was used for preparing maps to determine the proper locations for storing floods based on criteria containing slope, infiltration capacities of the sediments, wadi' runoff, land use, depth of ground water and wells density in the study area.

\section{Results and discussion}

\section{Digital elevation model (DEM)}

A digital elevation model (DEM) for the study area was created by using GIS (v.10.2) model by clip process using the polygon of catchment and extended DEM with a cell size of a value 0.00027777778 decimal degree as shown in Figure 2. The drainage pattern of the catchment is illustrated in Figure 3.

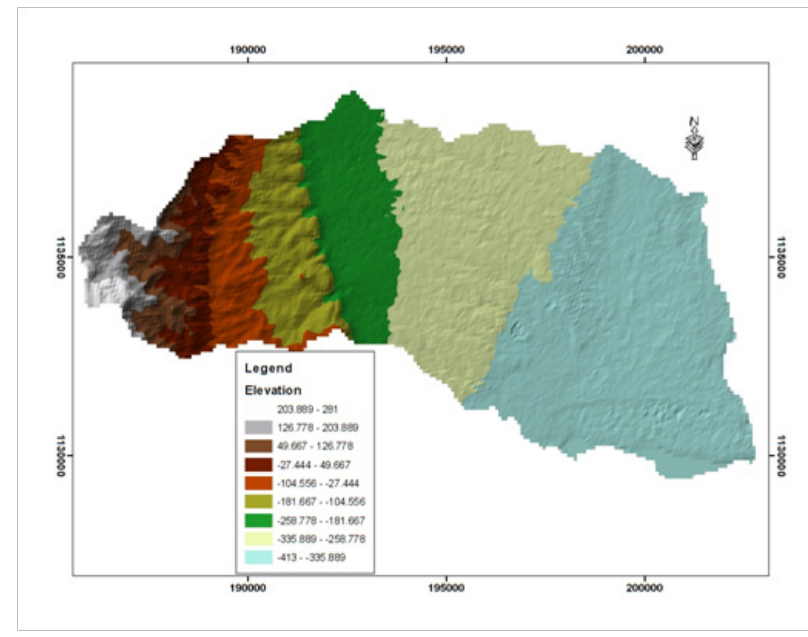

Figure 2 The digital elevation model of marar catchment.

\section{Measured monthly precipitation and temperature}

The annual precipitation grid is created for the entire catchment. The maximum monthly precipitation of $150 \mathrm{~mm}$ occurs in January while annual precipitation for the entire area is $414 \mathrm{~mm}$. The monthly average rainfall is illustrated in Table 1 . The maximum temperature 
is in August with a value of $28.8^{\circ} \mathrm{C}$. The minimum value is $13 . \mathrm{C}^{\circ}$ occurs in February. The maximum relative humidity in the catchment is $60 \%$ in January month.

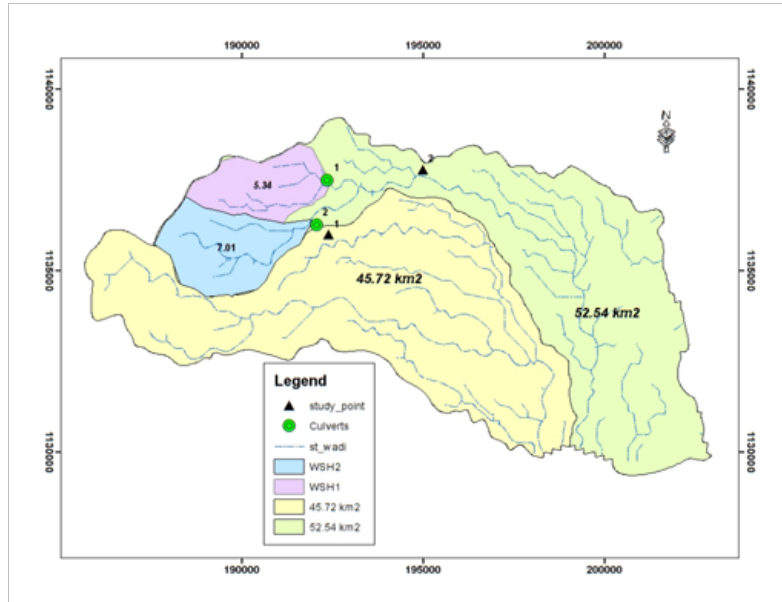

Figure 3 The drainage pattern of catchments of Wadi' Marar.

\section{The soil moisture content and evapotranspiration}

The highest water capacity in the study area of $100 \mathrm{~mm}$ is found in clay $^{18}$ and the lowest value of $12 \mathrm{~mm}$ is found in sandy soil textures. ${ }^{19}$ Soil moisture availability was assumed to decline linearly as the soil dries (e.g., only $50 \%$ of soil moisture is available when the soil is at $50 \%$ of field capacity). ${ }^{20}$ The American Society of Civil Engineers ${ }^{21}$ ranked the Turc method second behind the Penman-Monteith approach (which requires the estimations of temperature, radiation, wind speed, humidity). The Turc method includes a B1 model for humid areas and a B2 model for semi-arid regions. Since the study area is semi-arid, the B2 model is used, which computes Potential Evapotranspiration with a relative humidity as an adjustment factor. A relative humidity term is included in the following Turc equation (ASCE, 1990);

$P E T=0.013 \times(T /(T+15)) \times(R+50) \times(1+((50-R H) / 70))$

where, PET is the Potential Evapotranspiration, RH is the average

Table I Mean monthly rainfall $(\mathrm{mm})$

\begin{tabular}{llllllllllllll}
\hline City & Jan & Feb & Mar & Apr & May & Jun & Jul & Aug & Sep & Oct & Nov & Dec & Total \\
\hline Ramallah & 129.6 & 138.9 & 98 & 17 & 3.3 & 0 & 0 & 0 & 0 & 24.8 & 79.5 & 123.3 & 615.2 \\
Jericho & 35.8 & 31.2 & 24.7 & 1.9 & 0 & 0 & 0 & 0 & 0 & 7.1 & 21.6 & 33.4 & 166 \\
Jerusalem & 130 & 135 & 95 & 13 & 2 & 0 & 0 & 0 & 0 & 20 & 78 & 129 & 602 \\
\hline
\end{tabular}

Table 2 CN for hydrologic soil group

\begin{tabular}{|c|c|c|c|c|}
\hline \multirow[t]{2}{*}{ Land Use Description } & \multicolumn{4}{|c|}{ Curve Number for Hydrologic Soil Group } \\
\hline & A & B & C & $\mathbf{D}$ \\
\hline Good condition, grass cover on $75 \%$ or more of the area & 39 & 61 & 74 & 80 \\
\hline Fair condition, grass cover on $50-75 \%$ of the area & 49 & 69 & 79 & 84 \\
\hline Poor condition, grass cover on $50 \%$ or less of the area & 68 & 79 & 86 & 89 \\
\hline
\end{tabular}

monthly relative humidity value $(\%), \mathrm{T}$ is the temperature factor in ${ }^{\circ} \mathrm{C}$ $\mathrm{R}$ is the global solar radiation for the whole area in $\mathrm{cal} / \mathrm{cm}^{2}$ and $\mathrm{RH}$ is relative humidity. In this study ArcGIS (v.10.2) is used to estimate the potential evapotranspiration as a function of temperature and global radiation and a relative humidity in each month for a single point for the entire DEM. The main recharge area lies in the central mountains and the low amount of water recharge is found in the Jordan valley because of the presence of the Lisan formation, which has low permeability and transmisitvity. Annual runoff is calculated to be $4.5 \%$ of the total precipitation in the upper part, and $64 \%$ in the lower part of the catchment. ${ }^{3}$ Annual PET is calculated to be $1535 \mathrm{~mm} /$ year. The soil moisture deficit represents $70 \%$ of PET.

\section{Estimation of annual storm runoff}

No gauging stations of wadi flows have been conducted in the Wadi Marar catchment area. Runoff is estimated by using the Curve Number Method, which relates storm runoff to rainfall by a relationship that depends primarily upon the potential abstraction of water by soil storage. High potential abstraction means less runoff for a given rainfall, represented by a lower curve number. These curves are obtained by plotting the data for precipitation $(\mathrm{P})$ and runoff $(\mathrm{Q})$ for many watersheds. The main classification of the curve numbers indicates that: $0 \leq \mathrm{CN} \leq 100$ for impervious soil and surface water. The value of $\mathrm{CN}$ for various land uses on these soil types are shown in Table 2 and (Figure 4). Daily rainfall data from Ramallah and Jericho rainfall stations with adequate records from the water years (2004/ 2005 - 2012/2013) had been analyzed in terms of storms and frequency distributions. Calculations were performed for each storm of each water year of period of records. According to these calculations, the heaviest floods occur between November and March, and no significant floods occur in October and May. The maximum yearly runoff during the period of records was calculated using the following general formula of the SCS method for abstractions;

$$
Q=(P-I a)^{2} /(P-I a+S)
$$

Where, $\mathrm{Q}$ is the runoff (in inches), $\mathrm{P}$ is the rainfall (in inches), $\mathrm{S}$ is the potential maximum retention after runoff begins (in inches) and Ia is the initial abstraction (in inches). Initial abstraction constitutes all losses before runoff begins. It includes water retained in the surface depressions, water intercepted by vegetation, evaporation, and infiltration. Ia is highly variable but was approximated by the following empirical equation. 


$$
I a=0.2 S
$$

where, Ia is the initial abstraction which is usually equal to 1.45 Inches $(36.8 \mathrm{~mm}$ ), and $\mathrm{S}$ (in Inches) is the potential maximum retention after runoff begins. By eliminating Ia as an independent parameter, the remaining variables $\mathrm{S}$ and $\mathrm{P}$ (precipitation) allow the calculation of a unique runoff amount according to the following equation;

$$
Q=(P-0.2 S)^{2} /(P+0.8 S)
$$

Where, $\mathrm{P}$ is the precipitation and $\mathrm{S}$ is related to the soil and land cover conditions of the watershed through the curve number $\mathrm{CN}$. CN has a range of 30 to 100 , and $\mathrm{S}$ is related to $\mathrm{CN}$ by the following equation;

$$
S=1000 / C N-10
$$

Where, $\mathrm{CN}$ is equal to 58 and accordingly $\mathrm{S}$ is equal to 7.25 inches $(184 \mathrm{~mm})$

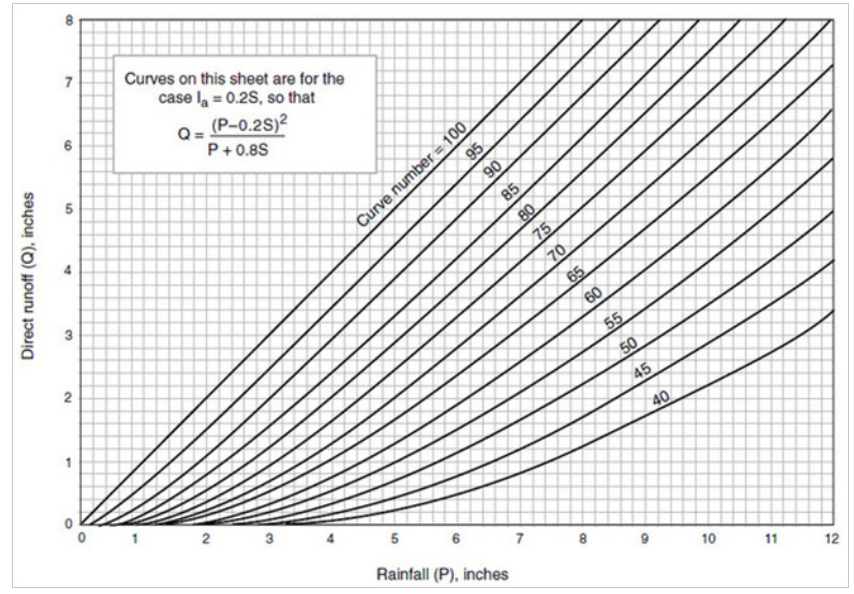

Figure 4 Solution of the runoff curve number SCN equations (Mays, 200I).

\section{Estimation of peak discharge}

The unit hydrograph approach is used in this study to determine the peak discharge values. The hydrologic characteristics of the drainage area such as, the area of the basin (A), hydraulic length (L) and the elevation difference $(\mathrm{H})$ between the highest point of the main stream and the outlet are calculated from the topographic maps related to the sub-catchment. ${ }^{22}$ The calculation of the unit hydrograph (UH) and the derivation of the flood hydrographs of 10 and 25 years return period for Wadi' Marar for the two sub-catchments area were performed. Among rainfall stations in Wadi' Marar sub-catchment area, only one have intensity duration frequency curves (IDF) curves closer to the outlet of Wadi Marar catchment area which located outside the catchment. The Ramallah rainfall station's IDF curves are selected for the use in this study. Five year Rainfall data for IDF of Ramallah rainfall station is used for the rainfall intensity. IDF and the $\mathrm{CN}$ methods were used to calculate the effective rainfall (runoff). The IDF curves are shown in Figure 5. Ten and twenty five years return period rainfalls for duration of 24 hours were obtained hourly for Wadi' Marar catchment area and illustrated in Figure 5. The results of effective rainfall of sub-Catchments of Culvert No.1 and Culvert No. 2 areas for the 10 and 25 years return period are used for the derivations of flood hydrographs. The incremental runoff values were applied to the UH with the time lag, and the individual hydrographs were obtained for each incremental runoff. These hydrographs give the total storm hydrograph. Table 3 shows the calculated maximum peak discharge was tabulated in cubic meters per second $\left(\mathrm{m}^{3} / \mathrm{s}\right)$ for the same return period respectively.

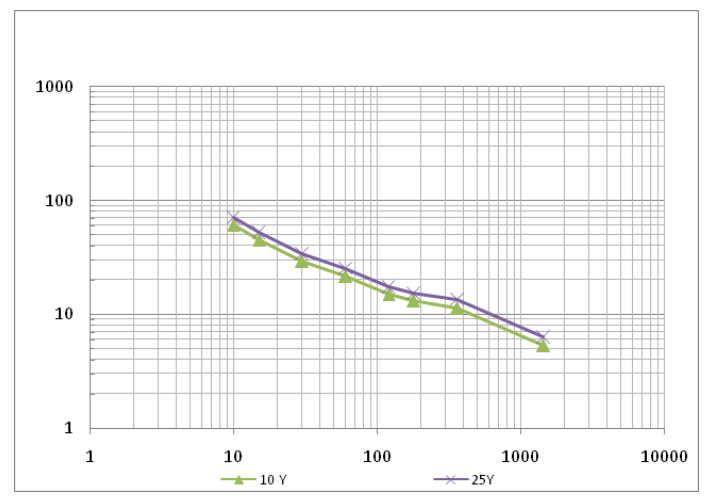

Figure 5 The log-log of rainfall intensity of 10 and 25 years return period for Ramallah station.

Table 3 Estimated maximum peak discharge in $\left(\mathrm{m}^{3} / \mathrm{s}\right)$ for two culvert sub-catchments

\begin{tabular}{llllll}
\hline Catchments Name & $\begin{array}{l}\text { Area } \\
\mathbf{K m}^{2}\end{array}$ & $\begin{array}{l}\text { I0Years Return } \\
\text { Period (cfs) }\end{array}$ & $\begin{array}{l}\text { I0Years Return Period } \\
\left(\mathbf{m}^{3} / \mathbf{s}\right)\end{array}$ & $\begin{array}{l}\text { 25 Years Return } \\
\text { Period (cfs) }\end{array}$ & $\begin{array}{l}\text { 25 Years Return Period } \\
\left(\mathbf{m}^{3} / \mathbf{s}\right)\end{array}$ \\
\hline Box Culvert No.1 & 5.34 & 805.4 & 22.81 & 1245.5 & 35.27 \\
Box Culvert No.2 & 7.01 & 1039.7 & 29.44 & 1607.87 & 45.53 \\
\hline
\end{tabular}

\section{Calculated evaporation}

The rates of evapotranspiration were calculated using the empirical evaporation formula of Wundt. This formula depends on the relation between precipitation and temperature. There is only one evaporation station in the vicinity of the catchment area, the Ramallah evaporation station. The amount of losses by evaporation is calculated to be 78.5 $\%$ using the following Wundt formula;

$$
E=\frac{P}{\left(0.59+\frac{P}{F(t)}\right)^{3}}
$$

Where, E: evaporation; P: precipitation; t: temperature

The maximum computed runoff for Wadi' Marar catchment was 6.8 MCM/Y in the water year 2004/2005 and the minimum runoff was estimated to be $0.53 \mathrm{MCM}$ in the water year $2005 / 2006$. In regards to the drainage divisions of the catchment, the northern subcatchment shows the maximum runoff of $0.5 \mathrm{MCM} / \mathrm{Y}$ for the water year 2004/2005 and the minimum runoff was estimated of about 0.2 $\mathrm{MCM} / \mathrm{Y}$ in the water years $2005 / 2006$. While the maximum computed runoff for the southern sub-catchment of about $0.37 \mathrm{MCN}$ and the minimum runoff was estimated to be about $0.12 \mathrm{MCM}$ as shown in Table $4 \&$ Figure 6 . The average annual runoff for the period of record Wadi' Marar catchment is $2.4 \mathrm{MCM} / \mathrm{Y}$. Thus, the estimated runoff 
coefficient is equivalent to $9.8 \%$ of rainfall over the 10 years period of analysis. The computed results were used for the calculation of water budget elements to estimate the infiltration rate per storm, as well as they were used in the estimation of runoff frequency analysis.

Table 4 Storm analysis and calculation of direct runoff for wadi marar catchment area water budget for the period (2005-20I3)

\begin{tabular}{|c|c|c|c|c|c|c|c|c|c|c|}
\hline $\begin{array}{l}\text { Water } \\
\text { Year }\end{array}$ & $\begin{array}{l}\text { Total } \\
\text { Runoff } \\
\text { (mm) }\end{array}$ & $\begin{array}{l}\text { Runoff } \\
\text { (MCM) }\end{array}$ & $\begin{array}{l}\text { Loss } \\
\text { Rate } \\
\%\end{array}$ & $\begin{array}{l}\text { Evapo } \\
(\mathrm{mm})\end{array}$ & $\begin{array}{l}\text { Evapo } \\
\text { (MCM) }\end{array}$ & $\begin{array}{l}\text { Total } \\
\text { Evap } \\
(\mathrm{mm})\end{array}$ & $\begin{array}{l}\text { Rainfall } \\
\text { MCM }\end{array}$ & $\begin{array}{l}\text { Total } \\
\text { Rainfall } \\
(\mathrm{mm})\end{array}$ & $\begin{array}{l}\text { Infiltration } \\
(\mathrm{mm})\end{array}$ & $\begin{array}{l}\text { Infiltration } \\
\text { MCM }\end{array}$ \\
\hline $2005-2006$ & 22.69 & 2.21 & 87 & 27.97 & 18.38 & 188.36 & 21.13 & 216.5 & 5.46 & 0.53 \\
\hline $2006-2007$ & 19.4 & 1.89 & 75.6 & 27.63 & 23.96 & 245.47 & 31.76 & 324.7 & 59.83 & 5.9 \\
\hline $2007-2008$ & 2.28 & 0.22 & 95 & 25.22 & 14.64 & $|50.0|$ & 15.44 & 157.9 & 5.61 & 0.58 \\
\hline $2008-2009$ & 5.79 & 0.56 & 90.8 & 38 & 17.22 & 176.47 & 19.01 & 194.35 & 12.09 & 1.22 \\
\hline $2009-2010$ & 29.53 & 2.88 & 73 & 33.84 & 23.85 & 244.33 & 32.73 & 334.7 & 60.84 & 6 \\
\hline $2010-2011$ & 2.8 & 0.27 & 94 & 24.63 & 15.84 & 162.3 & 16.89 & 172.7 & 7.6 & 0.78 \\
\hline $2011-2012$ & 9.56 & 0.93 & 77 & $20.7 I$ & 23.06 & 236.31 & 30.01 & 306.9 & 61.03 & 6.02 \\
\hline $2012-2013$ & 54.09 & 5.28 & 80 & 30.08 & 24.93 & 255.48 & 31.23 & 319.35 & 9.78 & 1.02 \\
\hline Average & $27.7 I$ & 2.35 & 39.2 & & 21.69 & 222.23 & 27.73 & 283.58 & 37.28 & 3.69 \\
\hline Rate \% & 9.77 & & & & & & 78.37 & & 13.15 & \\
\hline
\end{tabular}

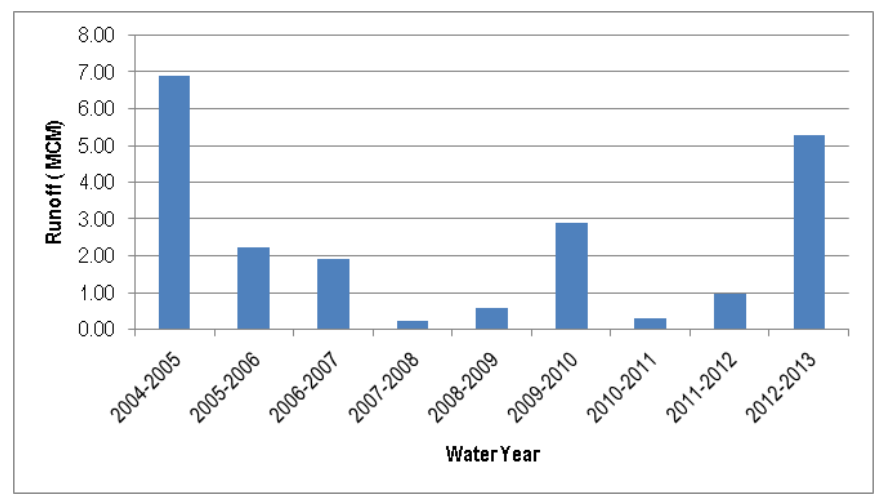

Figure 6 Estimated annual runoff and infiltration in Wadi' Marar catchment area for the period (2005-20I3) in MCM.

\section{Estimation of annual recharge}

The frequency and quantities of the rainfall storms are the controlling factors for groundwater recharge in the area. Four different scenarios are used to calculate the amount of recharge and illustrated in Table 4 from the Water years 2004/2005 up to 2012/2013. For the long-term average from 2004/2005 up to 2012/2013, the amount of recharge and runoff is about 4.03 $\mathrm{MCM} /$ Year and $2.6 \mathrm{MCM} /$ Year, respectively. Accordingly, the infiltration rate ratio is calculated to be of about $13.2 \%$ of the total volume of precipitation on the Catchment area as shown in Figure 7. Groundwater recharge was calculated using the following formula.

$$
I N F=P-R-P . E t-I a
$$

Where, INF is the infiltration, $\mathrm{P}$ is the precipitation, $\mathrm{R}$ is the runoff and P.Et is the evapo-transpiration.

The annual recharge calculations of other methodologies were applied in the catchment for output comparisons. The estimated annual recharge using DEM and Guttman \& Zukerman equation methodologies is $99 \mathrm{~mm} /$ year and $104 \mathrm{~mm} /$ year, respectively. The annual recharge estimation by chloride mass concentration is calculated to be $83 \mathrm{~mm} /$ year, while it is $114 \mathrm{~mm} /$ year by Goldschmidt ${ }^{23}$ method. The annual recharge in this case study for the Wadi' Marar catchment area ranged between (113.3-83) $\mathrm{mm} /$ year for all the different scenarios.

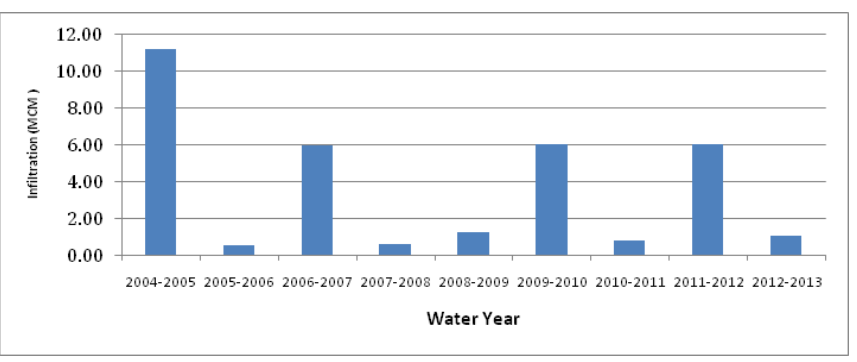

Figure 7 Estimated infiltration in Wadi' Marar catchment area for the period (2005-2013) in MCM.

\section{Management options for the flood preventions}

More options will be adjusted for the prevention of runoff catastrophic damage to the area. Building and constructing small scaled retention dams is to be recommended for the flood control in the catchment and the availability of stored runoff water will be used for agricultural or touristic use. Channeling the water in order to fill large digged rocky ponds by gravity in order to reach the gravel bottom of the layers. This bottom will act as a natural recharge membrane to the collected water. The gravel layers act as good layers for the infiltration of water into the underground. The pond will be designed according to the runoff calculations in the area. The collected water will used also for agricultural activities inside the Jericho area. Expanding the width and deepening of the main wadi' itself and number of ponds and sizes are dependent on the purpose and the available land in the 
sides of the wadi to be filled for flowing runoff- water for the sake of agricultural and touristic purposes. These ponds could be used for groundwater artificial recharge for the injecting the groundwater wells in the adjacent areas with the collected runoff water.

\section{Conclusion}

The geological, hydrological, hydrogeological and catchment delineations parameters were used for the calculations of the water budget in Marar catchment - Jordan Rift Valley. DEM was used for the estimations of the annual storm runoff in it. The result reveals that the runoff storm average is 2.35 million cubic meters per year in a ten year cycle (2004/2014). The peak of the storm runoff occurred in the hydrologic year 2004/2005 and has the value of 6.88 million cubic meters and the minimum value was 0.22 Million cubic meters in the hydrologic year 2007/2008. The study area has been subdivided into two sub catchment areas according to the flow channel discharge which has different degrees of flood flows. To avoid flooding catastrophic disasters, weirs, dams, or other means of flood defense infrastructures are recommended to be constructed.

\section{Acknowledgment}

None

\section{Conflict of interest}

Authors declare there is no conflict of interest in publishing the article.

\section{References}

1. Daghrah G. Pollution and Water Quality Assessment of Wadi Al Qilt Birzeit University, West Bank. 2005.

2. PCBS. Revised Population Projections 2015. Ramallah Palestinian Central Bureau of Statistics, West Bank. 2015.

3. PWA. Data Bank/Rainfall Data, Ramallah, West Bank. 2014.

4. Abed Rabbo A, Scarpa D, Qannam Z, et al. Springs in the West Bank: water quality and chemistry. University Bethlehem, West Bank and Gaza. 1999

5. Ali W, Hotzl H, Wolfer J. A hydrogeological study along Wadi Al Qilt between Jerusalem and Jericho, West Bank, Water and Environment. 1999;5-11.

6. Rofe Raffety. Consulting Engineers. Jerusalem and district water supply: Geological and hydrological report. Hashemite Kingdom of Jordan, UK 1963. p. $1-79$.

7. $\mathrm{CH}_{2} \mathrm{MHill}$. Monitoring program for water and wastewater sampling and analysis for Palestinian Water Authority, West Bank Integrated Water Resources Management Plan. 1999.
8. Abu Hilo F. Spatial and Temporal Variation in the Hydrochemistry and Isotopic Composition of the Groundwater in the Jordan in Jordan Rift Valley. Institute of Environmental and Water Studies, West bank; 2008.

9. PWA. Wells of the Jericho area and Jordan Rift Valley-Wells lithological profiles and groundwater data. Palestinian Water Authority-Water Data Bank Section. 2010

10. Shaheen H. Storm Water Drainage in Arid and Semiarid Regions: West Bank as a Case Study. An-Najah University Journal for ResearchNatural Sciences. 2002;16(2):125-139.

11. Zaineldeen U, Aish A. Geology, geomorphology and hydrology of the Wadi Gaza catchment, Gaza Strip, Palestine. Journal of African Earth Sciences. 2012;76:1-7.

12. Abu Safat M. Disasters Management \& Safety Buildings in Arab Countries , Ministry of Municipal and Rural Affairs \& Arab League. The Risk of Flood in West Bank. 2008;1:131-143.

13. Tarolli P, Borga M, Morin E, et al. Analysis of flash flood regimes in the North-Western and South-Eastern Mediterranean regions. Nat Hazards Earth Syst Sci. 2012;12:1255-1265.

14. Farhan Y, Anaba O. Flash Flood Risk Estimation of Wadi Yutum (Southern Jordan) Watershed Using GIS Based Morphometric Analysis and Remote Sensing Techniques. Open Journal of Modern Hydrology. 2016;6:79-100.

15. Braud I, Borga M, Gourley J, et al. Flash floods, hydro-geomorphic response and risk management. Journal of Hydrology. 2016;541(Pt A):1-5.

16. Alhasanat H. Flash Flood Assessment for Wadi Mousa City-Jordan. Procedia Economics and Finance. 2014;18.

17. Thieken AH, Kienzler S, Kreibich H, et al. Review of the flood risk management system in Germany after the major flood in 2013. Ecology and Societ. 2016;21(2):51

18. Saleh Y. Artificial groundwater recharge in Faria catchment hydrogeological study. An-Najah National University Faculty of Graduate Studies, West Bank; 2009. p. 1-146.

19. Building center. Geotechnical Report/Samer Issa Building. 2011.

20. Mather J. Climatology: fundamentals and applications. McGraw-Hill, USA; 1974. p. 1-412.

21. Jense ME, Burman RD, Allen RG. Evapotranspiration and irrigation water requirements. American Society of Civil Engineers, USA; 1990 p. $1-360$.

22. Natural Resources Conservation Service. Urban Hydrology for Smal Watersheds TR- Conservation 55. 2nd edn, USDA. 1986;1-164.

23. Goldschmidt M, Jacobs M. Precipitation over and Replenishment of the Yarkon and Nahal Hatteninim Underground Catchments. Ministry of Agriculture-Water Authority, Hydrological Service Jerusalem. 1959. 